\title{
Extraction of Essential Oil from Neem Seed by Using Soxhlet Extraction Methods
}

\author{
Bereket Tesfaye ${ }^{1}$, Tilahu Tefera ${ }^{1,2^{*}}$
}

Department of Chemical Engineering, Dire Dawa Institute of Technology, Dire Dawa, Ethiopia

\begin{abstract}
Extraction of essential neem oil from neem seed was carried by soxhelt extraction method using different organic solvents and parameters. Physico-chemical property of the extracted oil was also determined by using classical wet chemical method. Result revealed that, soxhlet extraction using hexane has 40.35\%; using ethanol-hexane mixture of 60:40\% volume proportion has $43.71 \%$, using ethanol $42.65 \%$ and using methanol $42.89 \%$. For all solvent type particle size has $355 \mu$, extraction time $1 \mathrm{hr}$ up to 3 hrs and applied constant and varies temperatures. At smaller extraction time, hexane produced oil yield greater than from ethanol and methanol. Actually, ethanol not produced oil at one hour extraction time. Thus, by effective determination of factors like particle sizes, solvent type, temperature, and time it is possible to investigate the result on the quality and quantity of neem oil. Surprisingly, mixtures of Ethanol and Hexane gave admirable results. Predominantly, ethanol-hexane mixtures of 60:40, and 40:60\% (volume proportions) gave better oil yields of $44 \%$, and $41.2 \%$ respectively than that of hexane $(40.35 \%)$ at 3 hours of process time.
\end{abstract}

Keywords - Neem oil, Particle size, Soxhlet extraction, Solvent type.

\section{INTRODUCTION}

Neem (Azadirachta indica A. Juss) is one of the very few trees known in the Indian sub-continent. This tree is belonged to Meliceae family and grows rapidly in the tropic and semi-tropic climate. It is also observed that this tree could survive in very dry and arid conditions. Neem seed is a part of neem tree which has high concentration of oil. Neem oil is widely used as insecticides, lubricant, drugs for variety of diseases such as diabetes and tuberculosis. This oil could also prolong leather goods when it is applied on them. There are several methods to obtain neem oil from the seeds like mechanical pressing, supercritical fluid extraction, and solvent extraction (Puri, 1999).

Neem Oil is a vegetable oil gotten from the fruits, leaves and seeds of neem tree. The tree is a member of the Mahogany family, with generic name Azadirachta Indica A.
Juss, it is an evergreen tree which is endemic to the Indian subcontinent and has been introduced to many other areas in the tropics. It has also been found to thrive in the semi tropics, arid and semi-arid climates in some countries including Nigeria where it is known as Dongoyaro, meaning - tall boy. The main reason behind the popularity of the neem oil is that it is used to treat few of the most common problems that the people face. The neem tree (Azadrichta indica) is among the fastest-growing trees, it attains a height of about 12-13 feet or 3.7- 3.96 meter and is a drought resistant tree (Bankole, 1997, Lalea et al. 1999).

Neem oil is generally light to dark brown in color. It has a bitter taste and an offensive odor similar to the combined odors of garlic and peanut. It comprises mainly of triglycerides (esters formed from a molecule of glycerol and three molecules of fatty acids), and is very rich in azadirachtin- the key component acting as insect repellent, anti-feedant, anti-fungal and anti-viral, among others, it is perhaps the most important commercial product of neem for organic farming and medicines (Adeeko \&Ajibola,1990, Mongkhol et al. 2004). Also, it is being increasingly used in manufacturing a large number of skin products: body soaps, body lotions, and beauty care facial packs in combination with other natural ingredients (Liaum et al., 2008).

The use of solvents and sohxlet extraction process for the extraction of neem oil is generally preferred choice. This is due to very high oil yield and less turbid oil obtained than from mechanical pressing. Due to the relatively low operating cost compared to supercritical extraction. The solvent hexane is the most commonly used, as well as preferred choice in extraction of oils from seed, even in neem oil solvent extraction. This is largely due to its availability at a reasonable cost and its suitable functional characteristics for oil extraction. Amongst such characteristics is its high solvent power for triglycerides at fairly low temperatures, non-reactivity with oil and oil miscella, as well as with equipment (Liaum et al., 2008).

The objective of present study was used soxhlet extraction method and some selected organic solvent to extract essential oil from neem seed. The effects of parameter such 
as temperature, time and particle size were studied. As the solvents, we used ethanol, hexane, methanol and ethanolhexane mixtures.

\section{MATERIALS AND METHODS}

\subsection{Materials}

Neem seed used for the study was obtained from Dire Dawa city. Dry oven was used for drying neem seed. Analytical balance was used for weighed neem powder. Sieve was used for separate fine particles from neem powder. Filter paper was used for filtration process. Heater Mantle was used for heating the solution during soxhlet extraction time. Soxhlet chamber was used for extraction process. Conical flasks and $100 \mathrm{~mL}$ volumetric flasks were used for measuring and solution preparation. Burette, beakers and pipette were used for carry titration process.

\subsection{Chemicals (Reagent)}

N-hexane, Methanol, Toluene, Ethanol and mixtures of ethanol and hexane were used for extraction of oil from need powdered. Alcoholic potassium hydroxide $(\mathrm{KOH})$, hydrochloric acid $(\mathrm{HCl})$ and phenolphthalein indicator were used for determination of saponification value.

\subsection{Size reduction and sieve analysis of neem seeds}

Neem kernel was crushed in KIKA-WERKE GMBH mill with sieve size $2 \mathrm{~mm}$. The sample was sieved using vibrated shaker with set of sieves sizes arranged in descending order $1 \mathrm{~mm}, 710 \mu \mathrm{m}$ and $355 \mu \mathrm{m}$.This is because to investigate the effect of particles size on yield and quantity of the oil. Therefore, using $355 \mu \mathrm{m}$ sieve is more effective and gives greater amount of oil than the else.

\subsection{Preparation of neem seed powder}

Neem seed used for the study was obtained from Dire Dawa city. Prior to use, the neem seeds were repeatedly washed to remove dirt and other impurities material, and subsequently dried in oven at $50^{\circ} \mathrm{C}$ until it attained constant moisture content. Then, neem seeds were pulverized to get the particle sizes of $355 \mu \mathrm{m}$ and prepared for extraction process (Maria et al. 2008).

\subsection{Method for extraction of neem oil}

$100 \mathrm{~g}$ of neem powder was placed into the thimble and placed in the soxhlet chamber $.500 \mathrm{ml}$ of selected solvents were placed in a round bottom flask and assembled for soxhlet extractor then the distillation process was begun. After completed the extraction process, the solvent and extractor were placed on water bath to evaporate the solvent. Then extracted neem oil was weighed by using the following equation:

$$
=\frac{W 1-W 2}{W 1} X 100 \ldots \ldots \ldots \ldots \ldots \ldots \ldots \ldots \ldots \ldots \ldots \ldots
$$

Where: $\mathrm{W}_{1}=$ Sample weight initially placed in the thimble and $\mathrm{W}_{2}=$ sample weight after dried in the oven (Natarajan et al. 2003).

Acid value and saponification value were determined according to the methods prescribed by AOAC (1984). Specific gravity and $\mathrm{pH}$ were determined according to the method of AOAC (1990).

\section{RESULT AND DISCUSSION}

Extraction of essential neem oil from neem seed was carried by soxhlet extraction method using some selected organic solvents and parameters. The effects of parameter such as temperature, time and particle size were studied. As the solvents, we used ethanol, hexane, methanol and ethanolhexane mixtures. Results were tabulated in the following tables. Three replicate measurements were carried for each parameters $(\mathrm{N}=3)$.

Table.1: show result of Soxhlet extraction using hexane with particle size $355 \mu \mathrm{m}$ and at constant temperature.

\begin{tabular}{|l|l|l|l|}
\hline Trial & Temperature( $(\mathbf{c})$ & Time $(\mathbf{m i n})$ & Oil yield $(\%)$ \\
\hline 1 & 70 & 60 & 37.02 \\
\hline 2 & 70 & 120 & 39.43 \\
\hline 3 & 70 & 180 & 40.35 \\
\hline
\end{tabular}

Table.2: Show results of Soxhlet extraction using hexane with constant particle size (355 um) and varies temperature.

\begin{tabular}{|l|l|l|}
\hline Trials & Temperature (0c) & Oil yield (\%) \\
\hline 1 & 70 & 41.08 \\
\hline 2 & 78 & 41.89 \\
\hline 3 & 86 & 42.41 \\
\hline
\end{tabular}


Table.3: show results of Soxhlet extraction using Ethanol-Hexane mixtures of 60:40\% of volume proportion at constant

\begin{tabular}{|l|l|l|l|}
\hline Trials & Temperature $\left({ }^{\boldsymbol{0}} \mathbf{C}\right)$ & Time $(\mathbf{m i n})$ & Oil yield $(\%)$ \\
\hline 1 & 70 & 60 & 25.06 \\
\hline 2 & 70 & 120 & 37.87 \\
\hline 3 & 70 & 180 & 43.71 \\
\hline
\end{tabular}

Table.4: Show results of Soxhlet extraction using Methanol with particle size $355 \mu m$ and at constant temperature

\begin{tabular}{|l|l|l|l|}
\hline Trials & Temperature $(\mathbf{0 c})$ & Time(min) & Oil yield $(\%)$ \\
\hline 1 & 70 & 60 & 25.38 \\
\hline 2 & 70 & 120 & 39.05 \\
\hline 3 & 70 & 180 & 42.89 \\
\hline
\end{tabular}

Table.5: Show results of Soxhlet extraction using Ethanol with particle size $355 \mu \mathrm{m}$ and at constant temperature

\begin{tabular}{|l|l|l|l|}
\hline Trials & Temperature (0c) & Time (min) & Oil yield (\%) \\
\hline 1 & 70 & 60 & - \\
\hline 2 & 70 & 120 & 40.54 \\
\hline 3 & 70 & 180 & 42.65 \\
\hline
\end{tabular}

Table.6: Show result of Soxhlet extraction using ethanol-hexane mixture 40:60\% of volume proportion with particle size 355 um and constant temperature

\begin{tabular}{|l|l|l|l|}
\hline Trials & Temperature (0c) & Time(min) & Oil yield (\%) \\
\hline 1 & 70 & 60 & 26.23 \\
\hline 2 & 70 & 120 & 36.42 \\
\hline 3 & 70 & 180 & 40.21 \\
\hline
\end{tabular}

\subsection{Physico-chemical properties of extracted neem oil}

In the present study the physico-chemical properties of the extracted essential neem oil was investigated by using classical wet chemical method. Results were presented in table-7.

\begin{tabular}{|l|l|ll|l|l|}
\hline solvents & $\begin{array}{l}\text { Acid value } \\
\text { KOH/g) }\end{array}$ & $\mathbf{( m g}$ & $\begin{array}{l}\text { Sap.Value } \\
\text { KOH/g) }\end{array}$ & Specific gravity & $\mathbf{P}^{\mathbf{H}}$ \\
\hline Ethanol & 17.35 & 195.56 & 0.85 & 5.38 \\
\hline Hexane & 18.05 & 202.04 & 0.90 & 6.04 \\
\hline $60: 40 \%$ hex/eth & 14.46 & 194.48 & 0.90 & 4.86 \\
\hline 40:60\% hex/eth & 17.11 & 198.36 & 0.89 & 4.98 \\
\hline
\end{tabular}

\subsection{Effect of Temperature}

Results obtained from the analysis showed that an increase in temperature generally favors an increase in oil yield. This phenomenon is due to the fact that oils are generally more soluble at elevated temperatures (Sen et al. 1992). At higher temperatures, the viscosity of the solvent is reduced while the diffusivity, as well as evaporation rate is increased. This increases the contact time between the solvent and the oil bearing material (Ayoola et al., 2014). From the above result, soxhlet extraction using hexane at constant temperature $\left(70^{\circ} \mathrm{C}\right)$ which has $40.35 \%$ and temperatures at $86^{\circ} \mathrm{C}$ has $42.41 \%$. At same temperature, the results showed

www.ijaems.com that ethanol -hexane mixture of $60: 40 \%$ volume proportions were better extraction liquid for higher yields of oil attained.

\subsection{Effect of Time}

Oil yield obtained (expressed in percent) was extraction time reliant. In general, the oil yield increased with increase in extraction time and there was no considerable increase after 3hour (Ayoola et al., 2014). Results shown from table1 , soxhlet extraction using hexane the time changed from $1 \mathrm{hr}$ to $3 \mathrm{hrs}$ the oil yield rose $37.02 \%$ to $40.35 \%$. In case of ethanol- hexane mixture of $60: 40 \%$ and $40: 60 \%$ volume 
proportions the oil yield rapidly rose $25.06 \%$ to $43.71 \%$ and $26.23 \%$ to $40.21 \%$ respectively. The same condition was appeared in methanol. Ethanol produced no oil at one hour of extraction time. As the extraction time increased, mixtures of $60 \%$ ethanol $40 \%$ hexane gave the maximum oil yield. These show that the combination of solvents favors higher oil yield compare to using these solvents separately.

Results of physco-chemical properties of extracted neem oil point out that, extraction using hexane solvent reported high acid value $(18 \mathrm{mgKOH} / \mathrm{g})$ and saponification value (202.04 $\mathrm{mgKOH} / \mathrm{g}$ ) than the other solvents. Acid value indicates the amount of free fatty acids presents in an oil. Acid value is good indicator of oil degradation caused by hydrolysis. Also higher extraction temperature increased the acid value because the extraction temperature influenced the hydrolysis of neem oil (Adeeko \& Ajibola , 1990). Saponification value indicates the average molecular weight of triglycerides in the oil (Fasina \&Ajibola, 1989, Ayoola et al., 2014). And also an increase in temperature increased the saponification value because higher temperature caused lipid to breakdown therefore reduced the average molecular weight of the oil (Fasina \&Ajibola, 1989, Adeeko \& Ajibola , 1990).

\section{CONCLUSION}

This project work was intended to investigate the influence of different factors such as Particle sizes, solvent type, temperature, and time on the quantity of neem oil. Variability of these operating conditions is the pre-dominant factors for the quantity of the oil.

There are different methods for essential oil extraction from neem seed. In the present study, soxhlet extraction method was selected. In this extraction method the maximum oil yield obtained was $43.71 \%$ by using ethanol-hexane 60:40\% solvent with particle size of $355 \mu \mathrm{m}$ and for three hours extraction time. The experimental quantitative difference in the quantity of the oil was due to particle size and extraction time variability.

Determination of the appropriate size of the particles and optimal time for the recommended particle size needs to have a consideration to get the maximum amount of the required product. Volume proportions of ethanol-hexane mixtures (60:40 and 40:60\% respectively) served as efficient solvent alternatives to the use of hexane in essential neem oil extraction.

\section{ACKNOWLEDGEMENTS}

The authors grateful to Dire Dawa University Institute of Technology Department of Chemical engineering, Ethiopia for providing all kind of bear and encouragement to carry out this thesis work.

\section{CONFLICT OF INTEREST}

The author(s) declare(s) that there is no conflict of interest regarding the publication of this paper."

\section{REFERENCES}

[1] Aalaa Elgasim Elshierh, Amina Bader Eldeen Edres, Mohammed Elmokhtar Abd Elaziz (2014). Extraction of Neem Oil from Neem Seeds.

[2] Adeeko K.A. and Ajibola O.O. (1990). Processing Factors Affecting Yield and Quality of Mechanically Expressed Groundnut Oil. Journal of Agricultural Engineering. 45: 31-43.

[3] AOAC. Official methods of Analysis. 14 ${ }^{\text {th }}$ edition, Association of Official Analytical Chemists, Washington, DC, (1984).

[4] AOAC. Official methods of Analysis. $15^{\text {th }}$ edition, Association of Official Analytical chemists, Washington, DC, (1990).

[5] Ayoola A.A., Efeovbokhan V.C., Bafuwa O.T. and David O.T (2014). A Search for Alternative Solvent To Hexane During Neem Oil Extraction International Journal of Science and Technology Volume 4 No. 4, ISSN 2224-3577

[6] Bankole, S.A. (1997). Effect of essential oils from two Nigerian medicinal plants (Azadirachta indica and Morinda lucida) on growth and aflatoxin B1 production in maize grain by a toxigenic Aspergillus flavus, Letters in Applied Microbiology, Volume 24, Issue 3, pages 190-192

[7] Fasina O.O. and Ajibola O.O. (1989). Mechanical Expression of Oil from Conophor Nut. Journal of Agricultural Engineering. 44: 275-287.

[8] Khraisha Y.H. (2000). Retorting of Oil Shale Followed By Solvent Extraction of Spent Shale: Experiment and Kinetic Analysis. Journal of Energy Sources. 22: 347-355.

[9] Lalea, N.E.S, Abdulrahmanb, H.T. (1999). Evaluation of Neem (Azadirachta indica A. Juss) Seed Oil Obtained by different Methods and Neem Powder for the Management of Callosobruchus maculatus (F.) (Coleoptera: Bruchidae) in Stored Cowpea, Journal of Stored Products Research, Volume 35, Issue 2, Pages $135-143$. 
[10] Liauw, M.Y., Natan, F.A., Widiyanti, P., Ikasari, D., Indraswati, N. and Soetaredj, F. (2008). Extraction of Neem Oil (Azadirachta indica A. Juss) Using nHexane and Ethanol: Studies of Oil Quality, Kinetic and Thermodynamic. Journal of Engineering and Applied Sciences.

[11] Maria Yuliana Liauw, F. A. Natan, P. Widiyanti, D. Ikasari, N. Indraswati and F. E. Soetaredjo, (2008). Extraction of neem oil (azadirachta indica a. juss) using n-hexane and ethanol: ARPN Journal of Engineering and Applied Science. 3, 2-4.

[12] Mongkhol khajornsilp D., Douglas S., Douglas P.L., Elkamel A., Teppaitoon W. and Pongamphai S. (2004). Supercritical $\mathrm{CO}_{2}$ Extraction of Nimbin from Neem Seeds-A Modeling Study. Journal of Food Engineering. 71: 331-340.

[13] Natarajan, V., Venugopal, P.V., Menon, T. (2003). Effect of Azadirachta Indica (neem) on the Growth Pattern of Dermatophytes. Indian Journal of Medical Microbiology. Volume : 21,Issue 2, page 98 -101.

[14] Puri H.S. (1999). Neem-The Divine Tree. Harwood Academic Publishers, Amsterdam. 